Maynooth Academic Publishing. ISSN 2712-0171. http://ojs.maynoothuniversity.ie/ojs/index.php/jmhds

\title{
Oral history: Utilising the Experience of Others
}

\section{Padraic Kennedy}

The Irish Defence Forces Leadership Doctrine emphasises the need for lifelong study and experiential learning, and the Defence Forces have considerable experience in managing oral history projects, including the Bureau of Military History and the Military Archives Oral History Projects. However, Irish doctrine does not outline any formal method to capture these experiences as a leadership development tool or to enhance organisational memory. The aim of this paper is to examine the value of utilising oral history for leadership development and organisational memory. It demonstrates that there is a risk to organisational memory unless a formal methodology is in place to capture the experiences of Defence Forces members and connected personnel. The use of tacit knowledge, which has facilitated the handover of information to date, is not sufficient nor is the written record alone. This paper shows that a combination of multiple primary sources, including the written record and oral history, provides an opportunity to enhance leadership development. It also demonstrates that the use of oral history provides an opportunity to capture the social and human aspect of Defence Forces activities to not only enhance organisational memory but to understand the context within which decisions were made.

The Irish Defence Forces Capstone Doctrine emphasises the need to build upon past achievements and to utilise Irish Defence Forces knowledge from sixty years of peacekeeping (DFCD, 2016, pp. 1-2). The Defence Forces Capstone Doctrine further outlines that capturing this overseas experience, alongside the study of military history, is a key element to guide the future. The Defence Forces have previously managed an oral history project called the Bureau of Military History which remains a key resource for understanding the events of the period from 1913 to 1921 . The Military Archives Oral History Project, initiated on 9 November 2017, now offers an opportunity for the Defence Forces to capture the experiences of its personnel, including overseas service. The Defence Forces Leadership Doctrine which 'codifies 100 years of experience and learning' further outlines the need for lifelong study, experiential learning through practice with skill, reflection and imagination (DFLD, 2016, p. 9) although there is no formal method to capture this experience. Notably, the use of Oral History programmes to develop organisational memory and promote learning from past events has been in existence in the US Military since the 1940s (Lofgren, 2006, p4).

Official written records can provide detailed accounts of events through the use of unit histories, patrol reports and communications logs, but the 'how' and 'why' units have adapted to changing circumstances is often missed. Key to following the Defence Forces Capstone Doctrine is the on-going development of its leadership which is about understanding the social and human aspect of decision making and applying them contextually. 
Alongside the Defence Forces stated value of overseas experience for doctrine, the use of Oral History can not only develop Defence Forces institutional history but provide a valued educational tool for Defence Forces leadership development. The use of Oral History in leadership development provides tangible real-life examples of the espoused values and competencies in Defence Forces leadership doctrine. It also provides a greater understanding and insight into Defence Forces organisational memory and why decisions were made. The purpose of this article is to evaluate the role of Oral History in enhancing Defence Forces leadership development and organisational memory.

\section{Leadership and the Defence Forces}

The use of an Oral History collection provides a significant opportunity for the Defence Forces to utilise the experiences of others and to enhance organisational memory, drawing on its own experience of managing Oral History projects alongside the facilities and expertise available at the Military Archives. The capture and use of Oral History testimony allows the passage of experience from current members of the Defence Forces, from which others can learn. Oral History testimony can also critically capture the experiences of retired members, enabling the Defence Forces Capstone Doctrine's aim to utilise sixty years of overseas experience and the study of military history for leadership development.

The publication of the Defence Forces Leadership Doctrine is an important recognition of the role of leadership as a 'core capability and competent leaders must practice life-long learning' (DFLD, 2016, pp. 1-1). Leadership and the military can be considered inseparable which is evidenced from the oft cited military expression 'the commander is responsible for everything the unit does or fails to do' (Wong, 2003, p. 658). Understanding an organisation and different viewpoints can assist a leader in developing critical capabilities. Wong also highlights the need for leaders to create a mind-set of continuous organisational transformation which can adapt from the garrison to the battlefield (Wong, 2003, p. 668). The Defence Forces Leadership Doctrine supports transformational leadership in line with Wong, to allow the Defence Forces to adapt to continually changing and increasingly complex operational environments (DFLD, 2016, p. xi). Defence Forces Leadership Doctrine outlines that this can be achieved through taking account of the historical and cultural setting of the Defence Forces. Experience can be utilised as part of an experiential decisionmaking process providing guidance and the confidence to make an ethical decision. Leadership is described as a 'rich and complex subject which requires skill, reflection and imagination that is part of life-long study, training and experiential learning' (DFLD, 2016, p. 105). Given the diverse environments that the military operate in and that leaders must be developed internally, it is not unusual that experiential learning plays an important role for leadership development in the military.

\section{Relevance to an organisation}

The Defence Forces Capstone Doctrine outlines that the Defence Forces draws on its own experiences from operations at home and overseas, the principals of which apply to all levels of leadership. This can be facilitated through the use of a top down and bottom up approach by capturing the experiences of senior and junior leaders. The benefits of capturing organisational memory and experiences is not unique to the military and also 
offers an opportunity for organisations to continue to operate during times of unexpected job losses, illness or retirements. Defence Forces Capstone Doctrine also further outlines its particular relevance to key decision-making appointments at all levels to facilitate the framing of their approaches (DFCD, 2016, p. ii). The Defence Forces Leadership Doctrine also highlights the importance of leadership development to meet the changing political, societal, economic, technological threats and challenges that the Defence Forces face which can be assisted through taking account of the historical and cultural setting of the Defence Forces (DFLD, 2016, p. xi).

While there is significant literature on leadership, 'we know surprisingly little about how leaders must develop a complex set of skills about how to improve the process' (Robinson, 2016, p. 1). The study of how the experiences of others are collated and presented is a key tool in Defence Forces leadership development in order to understand the complex range of issues and cultural setting of the Defence Forces. This paper aims to ascertain the value of Oral History in capturing the experiences of current members, retired members and individuals with relevant experience. It will focus on how these experiences can be codified in line with Defence Forces Leadership Doctrine and Defence Forces Capstone Doctrine for leadership development and the importance of capturing organisational memory so lessons can be learned and provide a greater understanding of why decisions were made. The article will utilise current leadership theory including the Defence Forces leadership framework from the Defence Forces Leadership Doctrine.

\section{PART 1. Oral history and the military}

The introduction above outlined the centrality of the experience of over sixty years of operations overseas in Defence Forces Doctrine, and the Defence Forces' experience in managing both medium and large-scale Oral History projects. The Military Archives Oral History Project has collected 239 interviews since its launch in February 2015 through to July 2020. The Bureau of Military History includes 1773 statements covering the period 1913-1921, which were accepted as part of a project between 1947 and 1957. The Military Archives Oral History Project and the Bureau of Military History can play a significant role in lifelong learning, experiential learning as part of the Defence Forces leadership development alongside capturing Defence Forces' organisational memory. Experiential learning will be further reviewed utilising Kolb's experiential learning model which envisages an on-going cycle of concrete experiences, reflection, abstract conceptualisation and active experimentation.

\section{Defence Forces Leadership framework}

The Defence Forces Leadership Framework incorporates the three levels of leadership of strategic, operational and tactical. Central to the framework upon which leadership is based is the character and competence of leaders within the Defence Forces, underpinned by six values: respect, loyalty, selflessness, physical courage, moral courage and integrity. It was designed 'as a single framework for leadership development' which aims to assist 'self-development and training establishments [who] can use it to educate' by way of developing, influencing, achieving and evaluating in order to achieve 'mission success'(DFLD, 2016, p. xii). 


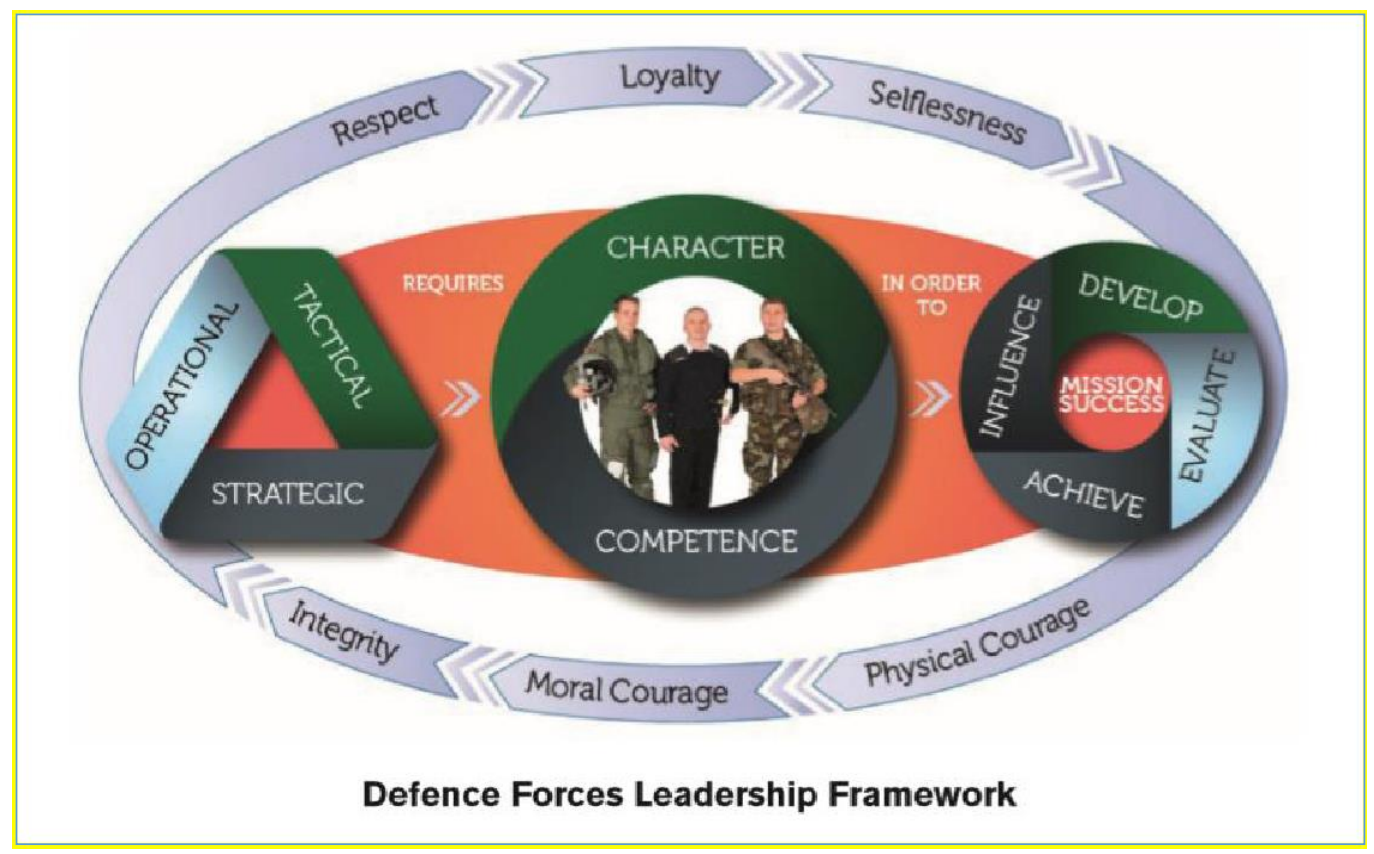

Figure 1 - Defence Forces Leadership Framework (DFLD, 2016, p. xii)

The Defence Forces leadership framework is part of the Defence Forces Leadership Doctrine which aims to guide and assist understanding of leadership development. The framework is based on a mission command philosophy which aims to promote 'decentralised command, freedom and speed of action and initiative, but is responsive to superior direction' (DFLD, 2016, p. 3-2). Alongside values, character and competence and a mission command philosophy, the Defence Forces has 'four essential actions or outcomes in what the leader does in the leadership process: influencing, developing, evaluating and achieving (IDEA)' (DFLD, 2016, pp. 2-4).

\begin{tabular}{|l|l|}
\hline Influence & The provision of purpose, direction and motivation \\
\hline Develop & Developing the team and developing self \\
\hline Evaluate & $\begin{array}{l}\text { Review, analyse effectiveness of plan, operation, system, plan, } \\
\text { unit, self and others in its purpose, mission and outcome }\end{array}$ \\
\hline Achieve & $\begin{array}{l}\text { Fulfilling tasks, taking care of people and managing resources } \\
\text { in mission success }\end{array}$ \\
\hline
\end{tabular}

Table 1- What the leader does

(DFLD, 2016, p. 2-4)

\section{Sources of Leadership in the Defence Forces}

The Defence Forces Leadership Doctrine also lists a number of sources for leadership development: 


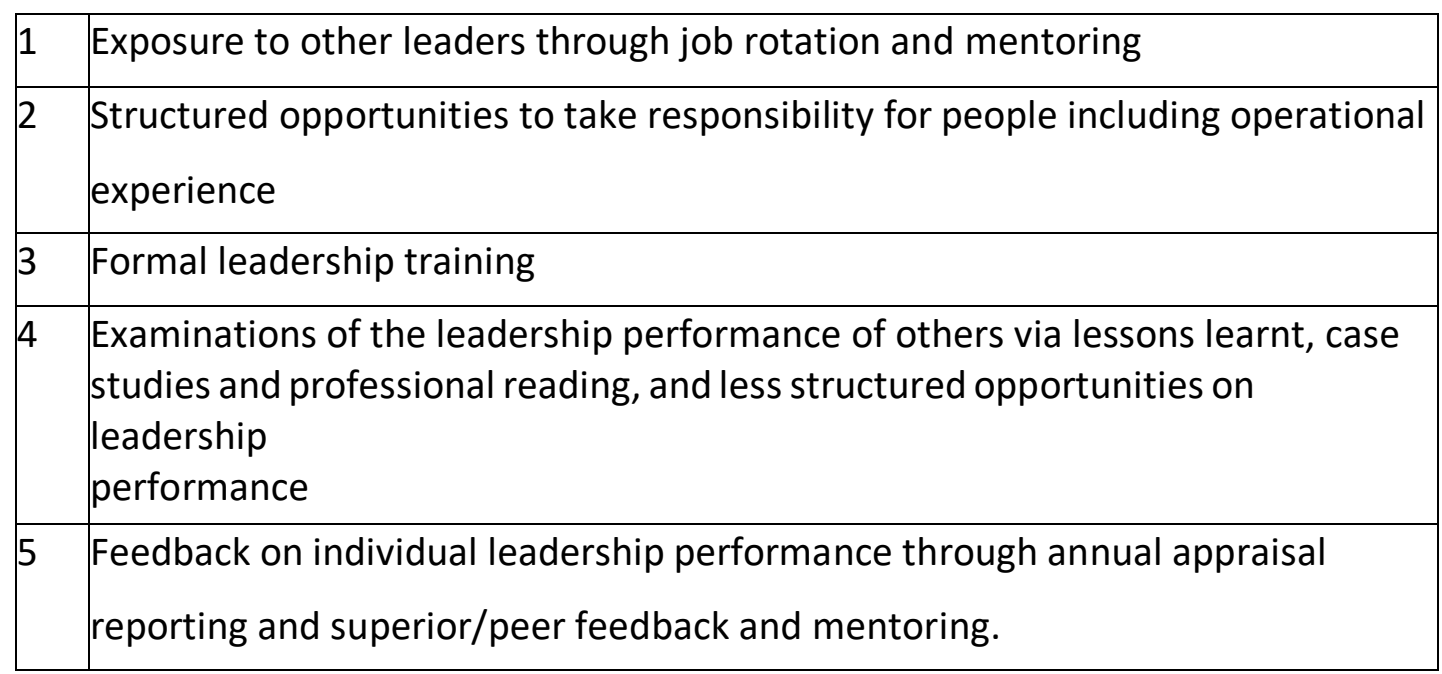

Table 2- Leadership Development Sources

(DFLD, 2016, p. 9-9)

The sources listed by the Defence Forces Leadership Doctrine provide opportunities for the integration of Oral History as a source in formal leadership training and the examination of leadership performance of others through Oral History case studies and through 'less-structured opportunities for reflection on leadership performance' (DFLD, 2016, pp. 9-9). Defence Forces Leadership Doctrine further outlines the inherent responsibility on all leaders to honestly reflect on and impart knowledge gained by experience and education, to ensure effective leadership for the future' (DFLD, 2016, pp. A-11). While no reference is made to Oral History for leadership development, the sources outlined by Defence Forces Leadership Doctrine provides a framework to integrate Oral History as a key tool in leadership development. The use of Oral History can provide a personal insight into activities and events which can assist in creating a greater operational awareness and allow leaders to draw on the personal experience of others.

As the legal repository of primary source material from the Defence Forces and the Department of Defence under the National Archives Act (1986), the Military Archives is the natural custodian and home for Oral History testimony. The use of Oral History testimony can be further utilised for leadership development and organisational memory using complimentary primary sources such as unit histories and private collections which are available for consultation at the Military Archives in Cathal Brugha Barracks and through its website www.militaryarchives.ie

\section{Experiential learning}

The definition of experiential learning as 'constructing knowledge and meaning from real life experience' is based on bringing the learner into contact with others with experience in a particular role (Yardley, Teunisssen, \& Dornan, 2012, pp. 161-162). Kirwan recommends the utility of experiential learning within the organisation [Defence Forces] be recognised as an enabler for leadership development (Kirwan, 2015, p. iii). Kirwan supports the value of personal experience for leadership development although the research focuses on the individual's personal experience rather than utilising that of others and the organisation. Kolb differentiates experiential learning theory from that of other learning theories with the assumption that ideas are not fixed but formed and reformed through experience providing for learning as a process (Kolb, 1984). ${ }^{4}$ Kolb outlines a four-stage cycle based on 
concrete experience, observation and reflection, forming abstract concepts and testing in new situations. This four-stage cycle allows for subjective experience whereby 'immediate or concrete experiences are the basis for observations and reflections. These reflections are assimilated and distilled into abstract concepts from which new implications can be drawn' (Kolb, 1999).

Critics of the experiential learning theory outline the failure to acknowledge cultural and social conditions of learning and a misinterpretation of Dewey's original thoughts on reflection and experience (Miettinen, 2000, p. 71). As with analysis of any record, the researcher must attempt to understand the context of the experience outlined by the interviewee in order to understand any subjectivity, potential bias or misinformed comment to critically evaluate the source. The need to evaluate any record or source, including Oral History testimony, requires the researcher to review it for context, potential bias or subjectivity. Understanding the challenges associated with the subjectivity of others' 'concrete experiences' gathered through Oral History interviews is common to the challenges of the written record. The experiential learning model provides a theory which can be utilised to engage the experiences of others captured through an Oral History program.

\section{Why Oral History?}

'Oral History relates to the collecting and recording of the memories and experiences of an individual or group' (Mac Conmara, 2016, p. 2). The role of Oral History in recording the history of institutions can create a greater understanding of how an institution operates and why decisions were made (Ritchie, 2016, p. 50). The use of the bottom up approach in the US Senate provided a broader historical narrative differing from the Columbia University project set up by Allan Nevins, which aimed to find out what made leaders think the way they did (Ritchie, 2016, p. 48). The bottom up approach relates to the recording of oral testimony using the lower ranks and in the top down approach, the oral testimony of the higher ranks is captured in the case of the military. The question of bottom up or top down approach is a decision for the individual project with both providing different perspectives and benefits. In the military, one can get a significant understanding of policy or leadership by interviewing the highest-ranking officer who is closer to the decisionmaking process. The value of the interview of a soldier, airman or sailor offers no less intimate access to how the military is run and the individual experiences of an event. The balance of both approaches can ensure that all groups remain equally represented. The author Donald Ritchie attended an Oral History Conference in 1987 at which time the bottom up approach was the dominant approach, resulting in a wide range of more senior groups being omitted. Such was the popularity that a collective comment at the conference was that a fisherman was more likely to be interviewed than a Member of Parliament, (Ritchie, 2016, p. 49).

As outlined by Professor Roy (Roy, 1988, p. 171), interviews from veterans can be augmented by written records demonstrating their complementary nature, the value of which becomes very clear when the interviewee saw what was happening and, importantly, knew why. The value of Oral History has long been utilised as a tool by international militaries and cultural centres including the Imperial War Museum for public education and 
learning (Philips, 2010, p. 114). The Imperial War Museum established the National Veterans Reunited Programme in 2004 to mark the $60^{\text {th }}$ anniversary of the events leading up to World War Two, producing over 1000 school projects and 3300 community projects. While written records can inform when a decision was made, it can often fail to capture the manoeuvring behind the scenes that proceeded decisions (Ritchie, 2016, p. 57).

\section{Origins of Oral History and the Bureau of Military History}

The origins of Oral History are not clear, with scholars often tracing it back to Greek History and the historian Herodotus' use of Oral History in documenting the Persian Wars. Other contested roots of Oral History date as early as 1122 -256 BC in ancient China when hired Chinese scribes documented people's history (Hong, 2016, p. 185). More modern examples on the origins of Oral History can be seen by the US Army collection of interviews of WW2 veterans in 1943 (Hong, 2016, p. 187) and from American journalist and historian Allen Nevins at Columbia University in 1948 who captured the thoughts and memories of politicians, judges and businessmen (J. Nyham, 2016, p. 23). Early Oral History attempts by the Irish government in 1933 aimed to capture a 'record of facts' from 'an Irish point of view' on the 1916 leaders and events subsequent to 1916 (Ferriter, 2003, p. 1). This early Irish attempt was limited in scope until a further Oral History endeavour commenced under the Department of Defence called the Bureau of Military History in 1947. The objective of the Bureau of Military History was to 'assemble and co-ordinate material to form the basis for the compilation of the history of the movement for Independence from the formation of the Irish Volunteers on 25th November 1913 to the 11th July 1921' (Director Bureau of Military History, 1957, p. 2). The Bureau of Military History operated from 1947 to 1957 accumulating 1,773 official statements and ten audio recordings from the period 1916 to 1921 to 'become one of the most widely consulted and used sources for the 1916 Rising and War of Independence' (Morrison, 2003, p. 1). Additional statements to the Bureau of Military History submitted outside of the agreed timeline or unsigned were not officially accepted although they were submitted as part of the administrative files of the Bureau. The first-hand accounts were taken from participants of the 1913 to 1921 period to include members of the British Army and civilians involved in events of the time alongside the Irish Volunteers providing different viewpoints on the same events. The Bureau of Military History was aware of the need to ensure a correct methodology was put in place, assisted by academia and historians, resulting in an accepted methodology in line with the thinking of the time (Morrison, 2003, p. 5). Training of interviewers, a strict methodology and detailed instructions for interviewers was provided to ensure the objectivity of the personal statement. The academic advisory committee also ensured external criticisms could be dealt with and the methodology validated (Military Archives, 2002, p. 2).

Your aim at all times must be to get from him an objective, factual record of events based on his own experiences. To that end he should be tactfully questioned on every point to ensure that what he tells is, in fact, what he knows and not something, which he has imagined, read or heard from someone else (S File 851, Bureau of Military History, 1948).

As with any recollection of past events, the oral statements were not infallible to the passage of time and the risk of exaggeration or loss of memory. The Director of the Bureau 
of Military History acknowledged these risks as he outlined that the interviewee should:

under no circumstances, be persuaded to agree to anything which does not accord with his own personal testimony. There must be no attempt to smooth out or adjust the story to make it more plausible or readable (S File 851, Bureau of Military History, 1948).

Initial criticisms of the Bureau of Military History by historians related to the methodology which would later be described as one that was 'most consistent' with modern thinking (Morrison, 2003, p. 5). Fortunately, this early criticism did not prevent the project from progressing and continues to be a valued source for the revolutionary period today, with over four million page views in its first five years from 2012-2017, accessed across 198 countries. As with any record, the oral statements are not without bias some of which have been described as egocentric, self-serving or unconvincing. However, the bulk of the statements provide 'measured accounts that convey an air of authenticity' (Mc Garry, 2011, p. 27). This previous management experience by the Defence Forces presents opportunities to build upon the success of the Bureau of Military History and learn from lessons outlined by the project staff including staff training, publicity, staff shortages and external validation of the methodology. The lessons of the Bureau of Military History have been applied to the Military Archives Oral History Project with the provision of training for interviewers including a detailed guide on conducting interviews, highlighting ethical and practical challenges of set up, equipment requirements, potential bias, ethics and permission from interviewees. The appointment of an Oral History practitioner as a consultant to the Military Archives Oral History Project also provided a forum which could validate the process and to ensure any challenges could be addressed quickly and effectively.

A more contemporary example of the use of oral testimony by students to learn about an organisation's history was conducted by the University of South Mississippi. Personal testimony of health clinic staff in the Southeast of the US was recorded by students for use as a classroom tool about management history and the evolution of an organisation (Topping, Duhon, \& Bushardt, 2006, p. 154). The findings provided an example of what could be achieved should it be adapted for use as a classroom tool. The results provided a brief description of the organisation under study, a learning tool for application of management theory and its relationship to history and provided unanticipated 'surprises' that enhanced the learning experience of the students (Topping, Duhon, \& Bushardt, 2006, p. 161). The non-anticipated discoveries included variations of opinions on important matters providing an insight into how and why decisions were made. The authors outline the benefits of understanding the history of the organisation in helping the students to understand the current culture and to associate theory to a real-life example. Collaborative engagement by the University with an Oral History practitioner from the Centre of Oral History and Culture, similar to the Bureau of Military History (Military Archives, 2002, p. 1), helped address concerns about ethical, legal and practical issues of an Oral History project (Topping, Duhon, \& Bushardt, 2006, p. 158) 


\section{The value of Oral History}

The definition of history by Professor David Lodge as 'the verdict of those who weren't there on those who were' (Ritchie, 2016, p. 56) provides an interesting perspective on the value of the personal testimony of those present. The value of Oral History can supplement the written document and becomes particularly important in understanding a topic in the absence of comprehensive records. The value of the Bureau of Military History statements as part of Oral History testimony to enhance the written record was referenced by Ferriter who describes 'as insufficient and inaccurate accounts of the Irish Revolution if based exclusively on existing documentary material' (Ferriter, 2003, p. 1). The use of Oral History can also support or disprove commonly held 'truths'. Research using the Bureau of Military History and other written sources provided an update to a commonly accepted figure for casualties during the battle of Mount Street in 1916 (Hughes, 2017, p. 22). This variation highlights the importance of utilising multiple sources. Utilising a wide range of sources, the generally accepted number of 234 casualties provided by General Sir John Maxwell in May 1916 provided an overestimation of 74 individuals. The use of multiple sources both from the $\mathrm{BMH}$ and other written records provided a figure of 160 casualties demonstrating a need to check even the most commonly accepted sources.

Oral History can also add significant understanding to institutional history and through oral biographies to understand what made leaders think the way they did (Ritchie, 2016, p. 48). The establishment of the Historical Office in the US Senate in 1975 utilised the oral interviews of senators to create a greater understanding of how the senate works, why the rules are the way they are and how the senate has evolved, thereby creating a better understanding of the Senate's role and function. In extending the scope of the project outside of sitting senators, the project collected testimony from ex-senators, their staff and families, providing both a top down and bottom up approach capturing important business which was often communicated in spoken and not written words (Ritchie, 2016, p. 57).

As highlighted by Ritchie, the use of Oral History provided an insight into how and why leaders, in this case US Senators, acted in the way that they did (Ritchie, 2016, p. 51). The use of Oral History can also act as a learning tool for the study of leadership using the experiences of others. As Gray highlights, the successful strategist requires natural ability and advantages that need to be developed using education and experience. As experience varies from person to person and is often an 'accident of time' (Gray, 2011,

p. 38), should the student who is not at such an 'accident of time' not utilise the experience of others? The relevance and importance of empathy and consideration of the views of others is further highlighted by Gerras who reasons that good critical thinking requires one to consider the views of others avoiding a narrow point of view (Gerras, 2008, p. 8). Given the complexity of events that shape the development of strategy, the utilisation of others' experiences can also assist researchers in integrating the experiences of others to support the written narrative.

Similar Military Oral History projects provide examples of possible opportunities for the Defence Forces. The Canadian War Museum Oral History Project includes former overseas commanders covering their command experience and their view of the world at that time (Brown, 2007, p. 63). This top down approach allows for a more strategic and wider view of a mission given the interviewees' exposure at both a political and military level. The bottom up approach allows a different viewpoint providing a lower level view of 
challenges and how they were encountered, making the testimony more relatable and relevant for lower leadership ranks.

An example of the utility of multiple sources was provided by Farrell and Giustozzi in their case study of Helmand and the Talban, utilising interviews from 53 Taliban Commanders from Helmand and 47 Taliban from other locations from 2011 to 2012 to try and ascertain how they operated from the point of view of the insurgency (Farrell, 2013, p. 845). A methodology to verify and authenticate accounts was put in place using subject matter experts and triangulation using multiple accounts of separated interviewees. The result provided an insight into the thinking of the Taliban and the manner of their return to Helmand which can be read alongside analysis of Western and Afghan governments (Farrell, 2013, p. 867). The use of multiple sources in this research including unit histories and personal testimony allows for further verification using triangulation of different sources.

Professor of Military History R.H. Roy of the University of British Columbia describes the limited value of war correspondents versus veteran interviews which fill in the gaps in official records and provide an idea of what it was like to be there and why events transpired the way they did (Roy, 1988, p. 169). Professor R.H. Roy argues this point in relation to war correspondents using secondary sources rather than the personal first hand accounts. The use of war correspondents remains valuable as it provides a different account of the same event from a different view. Both first-hand witness accounts and post event interviews by war correspondents may provide a wider view, context and triangulation of the events providing a method of verification and authentication of the event.

\section{Oral History in the US Army}

The origins of Oral History in the US Army can be traced back to the eighteenth century when the Massachusetts Provincial Congress initiated a series of interviews with veterans of the Battle of Lexington (Lofgren, 2006, p. iv). Further Oral History programmes were utilised by the US Army post WW2 which produced 79 volumes known as the Green Books, documenting the history of the war. Recognising the importance of Oral History, the US Army published the Oral History Handbook in 1992, putting in place a more formal process and methodology to capture the insights and spoken words of veterans to supplement the 'meagre' documentary records (Lofgren, 2006, p. 1). The objective of the US Army Oral History programme is to assist historians in the writing of official histories, to supplement official records to inform soldiers and leaders about the experiences of their predecessors and to bring to life museum exhibits using the words of the veterans (Lofgren, 2006, p. iv). Military historian Edward Coffman described oral testimony as a 'new military history' which added the human dimension to understanding 'how people respond to the challenge' (Coffman, 2001, p. 123). Coffman, in his writing, aimed to achieve a more comprehensive view of military history, one that included the human aspects from leaders and soldiers alike and how they responded to the challenges they faced. It is through this comprehensive view and understanding of how leaders responded to challenges that the Defence Forces can learn from the testimony of others.

Guided by Military History Army regulations (US Army, 1993), the programme is 
'conducted to obtain historical information that may not otherwise be recorded' (Lofgren, 2006, p. 2) echoing Ferriter's value of the oral testimony of the BMH in understanding the Irish Revolutionary Period (Ferriter, 2003). Lofgren highlights the importance of Oral History in understanding the complexities, challenges and initiatives carried out by senior leadership (Lofgren, 2006, p. 1). To avoid the dangers of taking memories as literal representations many years later, as highlighted by Morrison (Morrison, 2003, p. 7) in the Bureau of Military History, the US Army guide emphasises the importance of conducting an interview within days to capture the emotion and details of an actual event.

The US Senior Officer Oral History Program (est. 1970) is designed to record management and leadership techniques, provide an outline of their decisions and key events and to augment inadequate printed sources. Utilising a different methodology, interviews are conducted approximately three to five years after retirement to allow for longer reflection (US Army Heritage \& Education Centre, 2018) as compared to a more immediate interview as recommended by the US Army Oral History project. This period away from active service may also provide an opportunity for more open discussions from former military who may feel unable to comment while serving. The delayed method can also provide a suitable approach for the Irish Defence Forces for events of higher security classifications or more contentious issues. The Bureau of Military History also restricted access to transcripts under the promise of confidentiality until agreement was reached in the 1980s entailing closure until the last interviewee had passed (Ferriter, 2003, p. 4). This closure period played a likely role in providing more forthright testimony by interviewees who may have been reluctant to discuss contentious issues with the Bureau of Military History had immediate access to recorded testimony been in place. Thus, the collection of interviews immediately after an event may facilitate recall and clarity of details, but collection at a set period after the event provides an opportunity for the interviewee to reflect on an event, and greater freedom to comment.

\section{The Challenges of Oral History}

The challenge for Oral History is outlined as 'this fundamental dichotomy between history and mythology, which prevents modern Irish history from embracing oral history' (Beiner, 2017 , p. 4). As with any source, a researcher must look behind the argument to evaluate the information and why it is presented. The researcher should understand the context of the argument, any potential bias of the author, the author's knowledge of an event or the dangers of egocentrism as outlined by Gerras in relation to the risks of critical thinking (Gerras, 2008, p. 9). Oral History contains all the risks associated with the written record, including egocentrism, content and plausibility or the 'slippery account' avoiding an event that reflected poorly on the author or their associates (Mc Garry, 2011, p. 27). Criticisms in relation to objectivity and learning from past mistakes remain an issue for both written records and oral testimony. Eisenhower ensured the US Army Green books were captured objectively avoiding the 'celebratory writing that many official histories fall into' (Coffman, 2001 , p. 139) mirroring the Bureau of Military History Director's vision of objectivity. This was achieved through meticulous research, attention to detail and the appointment of a history committee which worked throughout the war, allowing lessons to be learnt from 'as much, if not more, from failure as you can from success' (Coffman, 2001, p. 139). Understanding the need to learn from mistakes, as well as success, will provide a more accurate account and increase the likelihood of 'honest accounts' from which militaries can 
learn.

Criticisms on the reliability of memory especially with the passage of time are acknowledged by practitioners of Oral History (Mac Conmara 2015; Morrison, 2003) and it is with this understanding that projects can introduce measures to separate memory and myth. Understanding the terms under which the interview takes place and associated details such as date of interview and training of the interviewer can avoid placing doubt on the integrity of the interview. Critics of Oral History have warned about the tendency to see the past subjectively and that history can only provide general lessons rather than concrete answers (Trevor-Roper, 1969, p. 15). The concerns outlined by Roper remain valid if the researcher fails to understand the context in which the interview was taken although few historians retain such a negative view of Oral History today. As outlined by Morrison, the greater the understanding of the context of an event, the documentary evidence available and the interviewee, the better the researcher is able to critically interpret the oral testimony (Morrison, 2003, p. 5).

The potential for capturing sixty years of Defence Forces overseas experience is evident from the wide range of military and civilian Oral History projects identified. The Defence Forces also has considerable experience in managing a medium and large scale Oral History project as demonstrated by the Military Archives Oral History Project and the Bureau of Military History respectively. The Defence Forces Capstone Doctrine outlines its development 'from a study of military history, from experience on operations at home and overseas' (DFCD, 2016, pp. 1-2) and taking account of the historical and cultural setting of the Defence Forces (DFLD, 2016). If doctrine is developed from the Defence Force's military history and cultural setting, which is cited as the basis for success (DFLD, 2016), it must ensure that all available sources are utilised as the education of personnel, training and experience is supported by doctrine (DFCD, 2016, pp. 1-3). US Army Oral History examples and the Bureau of Military History can provide a suitable framework to refine an Oral History project in order to capture this experience. Access to the personal experiences of Defence Forces personnel at home and overseas can not only provide a greater understanding of its organisational history, but also critically provide a key educational tool for leadership development. Utilising the experience of military service can help develop critical thinking skills, create a greater understanding of why decisions were made and improve situational awareness to ensure leaders are better prepared to make the right decisions when required. Kolb's experiential learning theory can be utilised to assess the value of experiential learning for leadership development. This will be conducted using 'concrete experience' [Oral History testimony] which is observed and reflected on, new abstract concepts formed by the student which can then be tested in the new situation as envisioned by Kolb's four stage cycle. The use of experience for leadership development has been identified in doctrine although it is not clear how the Defence Forces plans to capture the experiences of its personnel. This will be answered by engaging with academics and researchers experienced in Oral History and through a narrative and comparative analysis of written records and Oral History testimony from an overseas mission. 


\section{PART 2. Methodology for oral history}

\section{Mixed Approach}

The use of official records will fail to adequately capture the social dynamic of leadership and the operational environment that personnel from the Defence Forces work in while on overseas deployments. Silverman further outlines that the 'methods used by qualitative researchers exemplify a common belief that they can provide a deeper understanding of social phenomena than would be obtained by quantitative data' (Silverman, 2000, p. 8). The recognition of the value of both quantitative and qualitative data allows for recognition of analysing the personal testimony of military personnel as a social constructor along a subjective line which can be supported by the written record. The use of multiple sources and types allows a move away from an objective form of knowledge which provides for relationships and regularities which can be measured in terms of 'social facts' (Morgan \& Smircich, 1980, p. 493). This article although emphasising subjectivism as an approach, the use of extreme subjectivism is not supported which implies the impossibility of objective knowledge. The mixed approach discussed in this article utilises a case study from the $36^{\text {th }}$ Infantry Battalion which served in the Congo in 1960- 1961, 36 Infantry Battalion Unit History, interviews with veterans from the Congo, military archivists and researchers.

\section{The use of Unit Histories}

The use of unit histories as a primary source provides significant detail on what happened and when during a tour of duty overseas. While detailed, the unit history is made up of the following:

The ' $A$ ' input to the Unit History produced by the commanding officer shall be basically a summary of the six monthly ' $A$ ' reports, together with nominal roll, crime analysis, analysis of incidence of sickness, number of personnel found unsuitable for further overseas service etc (DF, Administration of Overseas Service, 2013).

Although the official Defence Forces instruction is not descriptive on what else should be included in a unit history (DF, Administration of Overseas Service, 2013), additional reference is made to monthly operations and logistics reports which contain detailed statistics on operational patrols, logistical stores and summary accounts of activities. The written record of a unit overseas is not associated with social insight and more suitable for document analysis using quantitative research methods. As outlined by Robson, 'instead of directly observing, or interviewing, or asking someone to fill in a questionnaire for the purpose of the research, we are dealing with something produced for a different purpose' (Robson, 2011, p. 350). The unit history was produced for the historical record and not for social insight or for understanding the complexity of the operational environment although it can be used to verify dates and events. It is for this reason that a mixed method approach in gathering and analysing data was utilised which drew primarily on qualitative methods, and to a lesser extent quantitatively, when reviewing the unit history. This method provides an opportunity for the triangulation of data from different sources which 
will assist in verifying testimony and help to enrich the findings of the research. Subjectivism is also criticised for its inability to compare circumstances as each version of reality is 'personal and community specific' (Holden \& Lynch, 2004, p. 12). The use of subjective experiences however is recognised in Kolb's four stage cycle of concrete experience - Observation and Reflection- Forming abstract concepts - Testing to new situation.

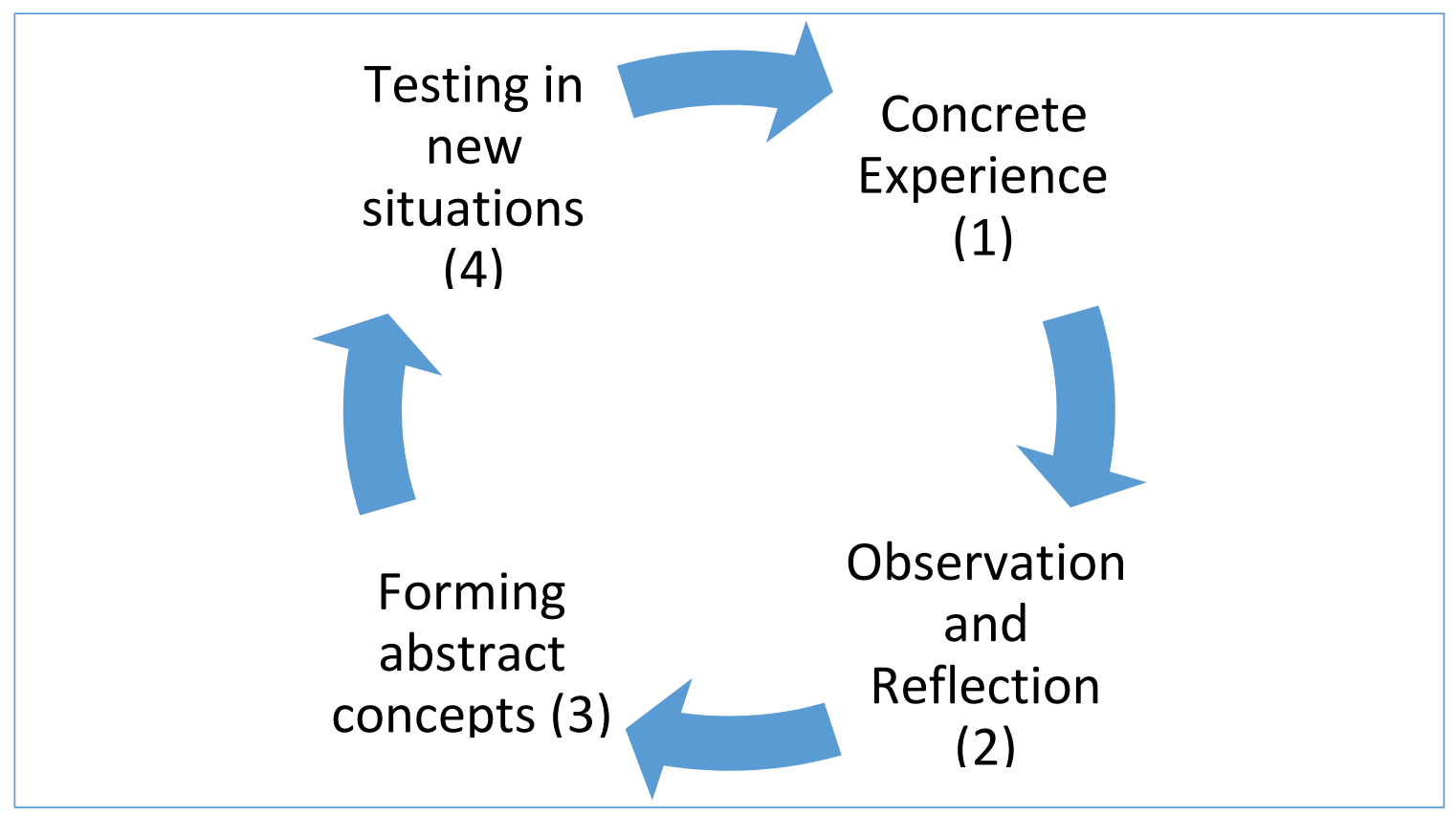

Figure 2- Kolb's Experiential learning cycle (Kolb, 1984)

\section{Case Study}

A case study design was utilised to examine the 36 Infantry Battalion unit history using document analysis and a quantitative methodology. The unit history of the 36 Infantry Battalion was selected as a sample of an overseas unit which served in the Congo from December 1960 until May 1961. The unit was involved in the 'Battle of the Tunnel' which resulted in Ireland's most decorated Company in the Irish Defence Forces (Reveille: Irelands Military History, 2018). The unit history of the 36 Infantry Battalion was encoded to ascertain common themes which were examined in conjunction with personal testimony of personnel from the same unit (36 Infantry Battalion Unit History, 1961). An interview with Col Peter Feely, a retired officer who served with the 36 Infantry Battalion in Congo was analysed alongside the interviews of personnel who have conducted interviews and research on the 'Battle of the Tunnel'.

\section{Semi-structured interviews}

The semi-structured interview allowed for the interviewee to express their personal experience or for the interviewer to explore additional information during the interview facilitating a greater insight into the context of a situation. Semi-structured interviews were 
conducted with a veteran of the 'Battle of the Tunnel' in the Congo and with seasoned researchers and writers who have utilised oral testimony extensively in order to get an appreciation of what can be learned from the experiences of others. It is acknowledged that the quantity of interviews conducted for the research was limited and can not provide definitive insight into all events that took place. It is also acknowledged that no two accounts will be the same as each participant sees events differently with their own unique experiences. The research is also aware of criticisms of unit histories which lack social insight and which may not reflect mistakes or incidents that reflect negatively. Document analysis of a unit history combined with the use of semi-structured interviews allowed for a revaluation of the potential of Oral History as a tool for leadership development and enhancing organisational memory.

\section{PART 3. Findings from the case study.}

Semi structured interviews were carried out with three retired and four serving members of the Defence Forces. The three retired members included:

- Lt Colonel Dan Harvey (Retd) who has published extensively on the Congo and UN operations,

- Colonel Peter Feely (Retd) who was in receipt of a distinguished service medal for his role as a Platoon Commander in the Battle of the Tunnel as a member of the 36 Infantry Battalion in the Congo and

- Dr James Mc Cafferty (Retd) who conducted his Doctoral research on the 'The Political and Military Aspects of Irish Army UN operations in the Congo 1960-1964' and is a former non Commissioned Officer of the Defence Forces who served in the Congo. Dr Mc Cafferty as a veteran and researcher of the Congo provides both first-hand experience of the Congo alongside detailed reflection as an academic of his experiences and fellow Congo veterans.

Lt Col Harvey (Retd) and Dr James Mc Cafferty had extensive knowledge of the use of both written and oral testimony in the conduct of their research. Col Peter Feely having served for over forty years and as a veteran of the Battle of the Tunnel was able to provide a primary source account of events in the Congo in 1961.

Two of the four serving Defence Forces members were selected and interviewed having currently or previously served as the Officer in Charge of the Military Archives with involvement in the management of the Military Archives Oral History Project. The one Officer was selected having personally provided a vignette for the Defence Forces Leadership Doctrine (DFLD) in relation to an engagement overseas and current School Commandant of the United Training School, Ireland (UNTSI). The final participant is an NCO who has conducted 220 interviews for the Military Archives Oral History Project as of 21 July 2020:

- Comdt Stephen MacEoin, former Officer in Charge, Military Archives,

- Comdt Daniel Ayiotis, current Officer in Charge, Military Archives, 
- $\quad$ Lt Col Timothy O'Brien, School Commandant, United Nations Training School Ireland (UNTSI) ${ }^{1}$.

- $\quad$ Cpl Michael Whelan, Interviewer for the Military Archives Oral History Project and curator of the Air Corps Museum at Baldonnel.

The unit history of the 36 Infantry Battalion, which served in the Congo from December 1960 until May 1961, was utilised as a reference tool to assist and verify the testimony of the interviewees. This process helped to facilitate analysis of the collected data, identify and analyse key themes and generate findings that will contribute to the application and use of oral history for the purpose of leadership development and capturing organisational memory.

\section{Data Analysis}

Qualitative analysis was carried out on the data obtained from the interviews. The semistructured interview used two sets of questions to reflect interviewees who had experience in managing or utilising oral history for research and for capturing personal experiences of a veteran of the UN mission in the Congo and from a serving Officer during UN service on the Golan Heights and current school commandant of UNTSI. The following areas were identified and grouped together into the following themes:

- Values based leadership

- Organisational Memory

- Difference between oral testimony and the written record

- Methodology/Triangulation

- Leadership lessons and reflection

\section{Values based leadership}

The Defence Forces utilises a 'values-based leadership doctrine centred on a mission command philosophy and details the principles by which leaders care for their people, develop the organisation and achieve mission success' (DFLD, p. 2-1). The Defence Forces values are described as 'the constants that underpin values-based leadership' which requires different characteristics in often unique contexts. As a result of this complex military context, the values differ from traditional civilian occupations where one may not be purposefully placed in harm's way. Of the six Defence Forces values, all of which were present, upon which the Defence Forces Leadership Doctrine is based: physical courage, loyalty, selflessness and moral courage were the most prominent from the data collected with a focus on physical courage in particular.

\footnotetext{
${ }^{1}$ Lt Col O'Brien held the appointment of School Commandant of the United Nations Training School Ireland at the time of interview in 2018.
} 


\begin{tabular}{|c|c|c|}
\hline Loyalty & Selflessness & Physical Courage \\
\hline Moral Courage & Integrity & Respect \\
\hline
\end{tabular}

Table 4 - Defence Forces Values (DFLD, 2016)

Although not specifically sought as part of the initial research, the recurring presence of these values represents an opportunity for the Defence Forces to validate its valuesbased leadership approach and act as tangible examples of the values the Defence Forces espouse for future leaders to reflect. The values were examined below as they now make up an integral part of the Defence Forces Leadership framework identified in the literature review.

The promotion of these values, including physical courage, provides a platform to capture what Comdt Mac Eoin described as 'something intangible in learning about past deeds and events, that draws out the more vocational aspects of soldiers and kind of inspires them to do things'. Both the Cadet School and the UN school regularly invite UN veterans to speak to their classes as a way of sharing their experiences, demonstrating the value in listening to the voices of veterans and their experiences overseas.

\section{Physical Courage}

Given the emphasis and reference to hostile incidents that occurred in the Congo and Lebanon by interviewees, it is not surprising that physical courage was the most cited value. The demonstration of physical courage and achieving the mission was clearly evident from the interviews. Cpl Whelan describes how veterans he had interviewed knew that:

they just get up, realise they have to do something here or we're all going to die or someone's going to get hurt or that's the threat. They just do it. You know the saying where the training kicks in, I think that's a big part of it because you wouldn't know what do otherwise if you weren't trained.

Cpl Whelan further describes the abundance of examples of physical courage that he has heard first hand including a cook who continued to feed the troops in their trenches during the Siege of Jadotville 'crawling along being picked at and firing at him while feeding them'. This embedded mission accomplishment role is further mentioned by Cpl Whelan who describes an incident of a former member of the Defence Forces who came across deceased members of his battalion that had been involved in an incident. Cpl Whelan describes the account of the soldier who 'jumped out of the car and ran over to check the bodies, as a robot... I wasn't feeling anything. It was just, this is what I had to do'. While Col Peter Feely describes the meticulous preparation and training he received in the Cadet School, which prepared him for the Congo, he also noted the lack of collective training and the low standard of training of the Army at that time, 'we must be the only army in the world that sends battalions overseas who haven't trained together for a couple of years and done all types of operations'. 
Interestingly, Cpl Whelan outlined that having interviewed over 120 people 'they never speak for more than two of three minutes about themselves'. This was also evident in Col Peter Feely's interview, as he himself had received a distinguished service medal for his actions during the Battle of the Tunnel in Congo, 1961.

\section{The Distinguished Service Medal With Distinction}

\subsection{Lieutenant Peter Feely}

For distinguished service with the United Nations Force in the Repu6fic of Congo, in displaying courage and leadership. From the time of his arrival in the Congo, Lieutenant Feely was engaged in action and he displayed coolness and control at all times. When his platoon was ordered to clear snipers from railway carriages in Elizabet hville, he personally handled the task dasfing in close to the carriages, lo66ing grenades through the windows before

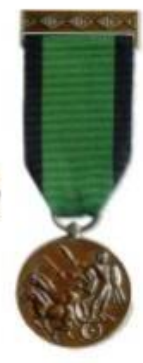
entering the carriages to clear them.

Figure 3- Citation of Lt Peter Feely, Distinguished Service Medal

The interview with Col Feely provided advice on leadership, motivation and knowing your men, but little of his personal actions or display of physical courage during this battle. The lack of willingness to speak about their own actions described by Cpl Mick Whelan demonstrates a degree of selflessness in recognising the role of the individual as subordinate to those of the team and organisation (DFLD, 2016, p. 4-3). This reluctance to discuss personal bravery or competence highlights the need for multiple interviews on a single event. Lt Col Dan Harvey (Retd) describes Col Feely's actions as follows:

as a result of interviewing those who participated in actions, I have written about most especially those central to the matters, and that was, when I pointed out the overt courage that it must have taken to undertake the actions theydid, Peter Feely in particular, while acknowledging in hindsight that perhaps, and the difficulty of the situations they faced, the train of events in the actions they undertook, seemed logical to them at the time, and as to be fearful, they admitted they were, and would not have trusted themselves had they not been, but somehow they were too busy to allow this fearfulness take hold.

The prominent value stated in many of the interviews is one of physical courage which placed the individuals in danger. Lt Col Harvey described their bravery during the Battle of 
the Tunnel as one which was expressed in:

the undertaking of the initiative, the course of action chosen as being the logical solution to the problem presenting, as someone had to act, to be in control. There was a certain boldness, Sean Norton's blasting his way back into the offense, the use of maximum force, an aggression was evident, the striking now while the iron was hot, killing as a means to an end.

The leadership philosophy of 'mission command' is clearly evident from Lt Col Harvey's description of the actions during the 'Battle of the Tunnel' who followed the very definition espoused by the leadership doctrine as a 'command that promotes decentralised command, freedom and speed of action and initiative, but is responsive to superior direction' is clearly evident (DFLD, 2016, pp. 3-2).

\section{Loyalty \& Moral Courage}

The loyalty to the mission and to their fellow soldiers provided much of the motivation to carry on with the task at hand. Comdt Mac Eoin described how learning about past deeds and events 'draws on the more vocational aspects of soldiers and kind of inspires them to do things'. Comdt Mac Eoin further emphasised the overarching need to understand the historical context of the values demonstrated by veterans who, although they did not verbally espouse the values, they did live them. 'Generally speaking, it doesn't make sense unless you refer back to loyalty, the army has always been loyal to the state, officers need to be loyal to their men because when such an event happened, those guys were loyal. I think it does have a bearing on all of those things [values]'.

The Defence Forces Leadership Doctrine outlines moral courage as carrying out actions even if they are unpopular. The vignette identified by Defence Forces Leadership Doctrine with Commandant Pat Quinlan is a now obvious example given his role in leading a Company in Jadotville, without the loss of life of his men in an extremely tenuous position. The siege of Jadotville took place over 4 days in September 1961 involving a Company of 150 Irish Peacekeepers serving with the United Nations in the Congo. The Company of Irish Soldiers under the Command of Commandant Pat Quinlan were heavily outnumbered by Congolese soldiers led by mercenaries who possessed air support and heavy weapons. Following an engagement against an estimated 2000-3000 soldiers (Whelan, 2006, pp. 50) the Irish Company was forced to surrender having run out of water, little hope of reinforcement and inevitable heavy loss of Irish life without justification. This decision to surrender was not well received at home and was to follow members of the Company until official recognition was provided in Athlone at a medal ceremony in December 2017 to mark the bravery of the members of A Coy, 35 Infantry Battalion. Commandant Quinlan's foresight to prepare defensive positions and his leadership is credited with the Company not suffering any loss of life in which 300 casualties were suffered by the opposing force. Such an example while not prompted during the interviews was referenced by three interviewees highlighting moral courage through enforcement of a strict regime of rehearsals and the digging of different trenches on consecutive days. Col Feely spoke of Quinlan as 'switched on big time' and the perception of the Platoon Commanders of Quinlan as being too harsh on the men. 
This perception of Quinlan changed following events in Jadotville, demonstrating the importance of maintaining discipline, rehearsals, training and possessing the morale courage in taking the difficult decision to surrender. Comdt Mac Eoin cited Comdt Quinlan as an example of a leader displaying moral courage providing a clear example of demonstrating what it means to be an officer and the role of an officer 'sometimes you need to make unpopular decisions and wondering when this will come to pass in my career and that always sticks in my memory'. Cpl Whelan agreed the decision to dig in and the disciplinary nature of Quinlan 'saved their lives because they were attacked with overwhelming force and they fought for five days. Only for he made them dig in, that's what saved the position, saved their lives and saved the situation'. This example of moral courage provides an opportunity of reflection as mentioned by Comdt Mac Eoin when envisioning the application of a past event in line with Kolb's four stage cycle.

\section{$\underline{\text { Physical Courage and fear }}$}

The presence of physical courage and fear was a regular theme in the interviews demonstrating the natural presence of fear in situations of danger and the need to control it. This is emphasised by Lt Col Harvey who supports the idea of discussing the natural connection of physical courage in relation to fear. Lt Col Harvey outlined that despite the fear, the individuals had to control this fear in order to accomplish the mission.

Only people who are afraid need to be courageous, they make a decision to do something they really do not wish to do, they control fear and carry on anyway. Can you teach it, or does it come from within? Whatever it is something we all would like to know about ourselves, if put to it, will I be brave? Have you ever discussed this as a Cadet, on a Young Officer's Course, even now on the Senior Command \& Staff Course?

Dr Mc Cafferty describes the natural feeling of fear when under fire in that it was 'absolutely frightening. Terrifying'. He further outlines that 'a soldier who tells you he was never frightened is dangerous. You get rid of him. If you are honest, you are frightened'. Dr Mc Cafferty shares the sense of it being 'absolutely normal' to be afraid. Cpl Mick Whelan also describes the tense situations he encountered in Lebanon which resulted in him getting 'awful anxiety in my stomach'. Cpl Whelan describes how it felt during the shelling of their positions during his deployment in Lebanon:

my heart would sink [be]cause l'd know I am going to be in here for two or three or four, at least six hours. It's going to be hopping, and it would be hopping. These are the things, so listening to the oral history is bringing that back to me. The stress of it.

Lt Col Harvey describes his research of veterans and their experiences which outlines the untold presence of fear which does not feature in the written record:

The element of fear existing in a situation, it being present, and likely to be felt by 
you and others, and needing to be overcome was a distinct, heretofore unspoken factor in situations that I found interviewees mentioned, this does not appear on written accounts. The ability, in actuality, despite the challenges, 'to grasp the nettle' and come up with a clear, and it can be an obvious and simple, course of action, is required.

Lt Col Harvey describes some of the same lessons outlined by Col Peter Feely of physical courage, determination, dealing with fear which needs to be captured so the Defence Forces can learn from them. The need to know that soldiers may need to be physically encouraged to move forward under fire; the requirement to be seen to be present to your troops during incidents; that you and others will experience fear, and other important points, that have arisen from 'real-life, actual experiences, hugely life-saving important lessons learned have not been institutionalised was mind-boggling'.

\section{Organisational memory}

The codification of the Defence Forces' overseas and domestic service is central to learning and building upon the experiences of its members. Walshe and Ungson argue that 'interpretations of the past can be embedded in systems and artefacts as well as within individuals' outlining that organisational memory is constructed from both levels of the individual and the organisation (Walsh \& Ungson, 2001, p. 61). The use of organisational memory in learning has both detractors, who see it as an inhibitor to change, and supporters who see its role in facilitating organisational learning (Walsh \& Ungson, 2001, p. 72).

Kolb's four stage cycle provides a learning opportunity for reflection on experiences which can help form new abstract concepts which can then be adapted to suit the current environment. Cpl Whelan outlines that the 'Irish Defence Forces don't have a good understanding of themselves. They don't have an understanding of their own identity and the people don't have an understanding of the Irish Defence Forces and what they do abroad and at home'. The passage of information overseas on completion of a mission in the short term is primarily carried out by way of a 'handover-takeover (HOTO) from the outgoing to the incoming individual or unit. The HOTO is an important method for providing the formal and informal knowledge deemed necessary for a successful mission. The importance of the HOTO and tacit knowledge in the absence of a peacekeeping doctrine or codification was highlighted by a former Assistant Chief of Staff to Lt Col O'Brien when describing that it was almost a sense of pride to everybody deployed overseas that they would ensure the person following them would get a professional handover'.

The lack of a process for recording this information beyond the one to one HOTO provides a risk of loss to the Defence Forces' organisational memory. This is particularly true when the information is no longer immediately required. Cpl Whelan outlines the lack of records relating to the deployment of military personnel to Rwanda. Cpl Whelan describes the interview with a former Defence Forces member who served in Rwanda in 1994 becoming 'emotional, quite a few times, because he was never debriefed by the Army about the Rwanda trip'. This was also the case for other small, two to three-person deployments, who were never debriefed presenting a gap in the Defence Forces' 
organisational memory. The deployment of archivists took place to Lebanon in March 2018, as part of the Military Archives Oral History Project, to record testimony of the local population which will greatly enhance our understanding of how the DF are viewed and their views on our shared history since the Defence Forces deployment in 1978. Comdt Ayiotis outlines 'through oral history testimony, much more so than written records could, the strength and significance of the Irish/Lebanese relationship is conveyed, not only through the words of the interviewees but through tone, pauses and vocal cues'. Comdt Ayiotis also outlined the challenges of the physical and therefore emotional distance that current deployments provide and the role these 'interpersonal relationships prove vital to saving Irish lives and informing decisions of senior officers'. The Irish battalion posts had previously been co-located with the local Lebanese population in the villages with daily interaction. The current disposition of the Irish battalion is located in a position away from the villages and interaction with the local population.

A greater understanding of the local population will assist the Defence Forces in the conduct of their operations in line with modern stabilisation doctrine and best practice as outlined by Rottman 'both the narrow and the broad concepts of stabilisation struggle with a tendency to overstate the knowledge and the power of external, international 'stabilisers' over local political dynamics in a crisis, conflict or fragility scenario' (Rottman, 2016, p. 6). The collection of testimony of the local population in Lebanon by the Military Archives is also in line with the US Senate approach of interviewing individuals outside of the organisation to get a wider and valuable difference in view.

The lack of information and records on how the Defence Forces deployed to the Congo was frustrating for Dr Mc Cafferty (in his capacity as an historian) who described not knowing anything about the decision-making process of the then Chief of Staff 'he had to go off and do it, but how did they do it? It was sometime later that I discovered there had been a plan, because two or three years earlier, they looked at the possibility of sending troops to the Suez'. The use of similar problems provided some background work which appeared to have been used in the Congo having planned a deployment to the Suez two to three years earlier. Dr Mc Cafferty discussed how limited records remain in relation to the deployment 'one of the things I hate about the Congo research was the absence of the written record'. Having the first-hand experience of the Congo from the 'bottom up', Dr Mc Cafferty further describes that it would have been of significant benefit to be able to speak with the leadership of the time and 'that would have been priceless to be able to say, 'I talked to Colonel Hale, he remembers the dismay at being asked, or he thought, Great or I don't know'. Dr Mc Cafferty highlights the need for duel use of a bottom up supported by a top down approach to testimony collection.

\section{Difference between oral testimony and the written record}

The idea of Oral History in providing a greater understanding of how an organisation operates and why decisions were made (Ritchie, 2016, p50) is shared by the interviewees. Lt Col Harvey outlines the importance of oral testimony providing a greater understanding beyond a completed and one-dimensional record.

The written record is just that completed and one-dimensional, and if brief and otherwise limited, offers no scope for further exploration. The person - to - person engagement with the first-hand, 'real world', on the ground perspective, spoken by 
and through the perspective of the mission/incident participant, is simply irreplaceable and of the utmost value, given that it is both accurate and true, but your thorough preparation and prior research ought [to] ensure you are aware of this. The authenticity of the first-hand interview account is paramount, the interview experience presenting you with the opportunity to 'probe ' deeper and further into the content matter of the challenges faced in the mission area.

Cpl Whelan supported the idea that Oral History provides an opportunity to find the 'information that gets through the cracks' and a 'richness' that was extracted when speaking to veterans as opposed to reading the written record. Cpl Whelan while conducting research for his MA thesis outlined that the unit history 'while rich in information, but nothing compared to what I learned off the individuals and doing my own research afterwards'. He cited the need for clear and concise information required under military writing which often 'pick[s] and choose[s] what they're going to put in'.

The subjective nature of selection of information to be included was discussed by Gerras (Gerras, 2008, p.9) and the risks of a slippery account as suggested by McGarry (McGarry, 2011, p.27) when attempting to self-document a 'unit's history' or avoiding an account that reflected poorly on the author or associates (Coffman, 2001, p. 139). Lt Col $\mathrm{O}$ 'Brien suggests that the testimonies should be 'complemented by the unit histories and then supported by academic articles'.

As outlined by Lt Col Harvey, the use of an interview can ascertain what happened in reality and explore further that which may not be captured in the written record. Col Peter Feely described being called into the operations room the evening before the 'Battle of the Tunnel' to discuss the operation ${ }^{2}$. Col Feely explained that he was asked his opinion on the operational instruction to be carried out. He described being presented with the Brigade orders and disagreeing with the understanding of the orders and the proposed action to be taken 'Do we take the tunnel? No, this says we don't. We haven't been ordered. The Irish Battalion haven't been ordered to take the tunnel. They had been ordered to take point B. Be ready, if ordered [to take the tunnel]'.

Col Feely further remarked that they 'probably could have taken the tunnel without any casualties the next day, no problem'. Col Feely described how the operational order from higher headquarters included that they were to be prepared to take the tunnel on receipt of a further order and that the Brigade headquarters were 'wide eyed and astonished that we'd gone and done that'. The reason why A Coy proceeded to take the tunnel as an immediate task rather than a 'be prepared to' order cannot be fully known given the Company Commander is no longer alive. Col Feely emphasises the lesson of understanding what you are being tasked to do.

\footnotetext{
${ }^{2}$ The Battle of the Tunnel took place on $16^{\text {th }}$ December 1961 in Elizabethville, Congo and remains the largest Irish Defence Forces offensive military operation resulting in the loss of three soldiers lives.
} 


\title{
75. RUINDA
}

\author{
A Coy, 36 IRISH Bn, \\ ONOC, \\ The TUNAEL, \\ ELIZABETHVILLE.
}

23.12 .61 .

REYORT ON THE ACTION AT THE TUNNEL

1. MLSSION OF $36 \mathrm{BN}$. $\quad 36$ Irish Bn will seize and hold RJ KASENGE/IOUXEW BOURG (Pt C) through Pt F on BAVONNIER and exploit fwd to Pt G, in order to secure the rt flank of the Swedish attack, prepared to seize and hold the Tunnel.

2. TASK OF A COY.
a. A Coy will relieve 12/14 SWEDISH Bn at ELAKAT (Pt B) as from $10.00 \mathrm{hrs} 15-12-61$ with one pl.
b. A Coy from its posn in front of ELAKAT will be prepared to move fivd and seize and hold the TUNNEL.

Figure 4- Report on the action of the tunnel. 36 Infantry Battalion Unit History

The Brigade Order ordered ' 36 Irish Bn' to 'Be prepared to seize and hold the TUNNEL on capture of X-rds Kasenga/Luxembourg' (36 Inf Bn unit history, 1961, p. 61). The report on the Tunnel dated 23 December 1961 also outlines the order to take the tunnel when ordered to do so and not as an immediate task (36 Inf Bn unit history, 1961, p. 75). Col Feely tells how this discrepancy between the actions taken and the written record may have cost unnecessary loss of life. Interviews conducted by Lt Col Harvey showed that they 'were happy to be moving and visit an assault on the enemy' demonstrating a desire to get their assigned task completed. Multiple sources at different levels of command from both top down and bottom up are required to assist in capturing the background of the decisions made and the event itself. The further exploration of why the tunnel was taken immediately is not possible using the written record alone but could be clarified using multiple accounts rather than a singular account. The use of personal accounts may also reflect differing circumstances that may not have been known when the original written order was promulgated.

\section{Oral history methodology}

The written record can often provide an official record or details of an organisation or event which while accurate may not provide the social insight of an individual's testimony. The combination of both the written record combined with primary source testimony can provide a 
greater insight avoiding singular accounts whether written or oral. Both methods can be utilised to collaborate, add context or contest details on an event.

\section{$\underline{\text { Triangulation }}$}

The Military Archives Oral History Project adopted a sound methodology assisted by the employment of a consultant to ensure ethical, legal and practical procedures were put in place by the staff and interviewers. The triangulation of testimonies utilised by Farrell and Giustozzi in their case study of Helmand and the Talban allowed accounts of the interviewees to be verified and cross checked for accuracy and authenticity (Farrell, 2013, p. 845). This method of triangulation was used by Comdt Mac Eoin also using a 'multiplicity of interviews to make sure you have corroborated your story. In my research, you would have looked at more than one source'. Cpl Mick Whelan outlined the use of triangulation of testimony assisted in the verification and the authenticity of the testimonies. 'I didn't tell each person that I knew the story, but I didn't know it on the detail that I have it recorded. To get the three or four people telling you their side of the story and they are all matching up, one or two little things because they all don't know what the other person saw. That is absolutely fascinating'. The use of multiple accounts will also provide an approach to understanding the actions of individuals who may be reluctant to discuss their own actions as discussed by Cpl Whelan. The conduct of interviews with Distinguished Service Medal holders like Col Peter Feely may also require multiple accounts to gather a fuller picture of events if individuals do not wish to discuss their personal actions.

The use of a group interview with Col Sean Norton was also suggested by Col Peter Feely who 'might remember that process and jog my memory on other aspects'. While group interviews poses different challenges, the collaboration of two participants may assist when significant time has passed or to bring multiple view points on the same subject. Col Feely outlined that once 'they start talking, I'm sure other things would come back to me'. The use of group oral history interviews and the potential challenges they pose are highlighted by the Military Archives Oral History Project manual (Mac Conmara, 2016, p. 28). The use of multiple testimonies for an event was supported by Dr Mc Cafferty as he described that 'I got more than I bargained for, in the sense that people told me their experience which was not the same as mine'.

\section{Preparation}

The use of written documentation to support the collection of oral testimony was utilised by the Bureau of Military History chronology. The Bureau of Military History Chronology recorded key dates and events from primary sources, contemporary press and national journals of the period in addition to secondary sources published after the period. The use of the unit history acts as a guide for the interviewee to help "probe them and get more out of them. It is not lies, because you do your research before' according to Whelan. Comdt Mac Eoin supports preparation using secondary accounts to assist with preparation for an interview and the need to look at a 'multiplicity of sources to make sure you have corroborated your story'. Comdt Mac Eoin also cautioned against the sole use of unit histories which may be 'sanitised because they are the official account' which couldn't comment overly negatively or provide 'political insight'. This preparation prior to interview is supported by the Military Archives Oral History Project guide which outlines that 'the 
more research and preparation is undertaken, the more comfortable and productive the interview will be. This will minimise discomfort for the interviewee and will create optimal conditions for a free flowing and rich exploration of memory' (Mac Conmara, 2016,p. 10). Whelan outlines that he commences the interview with questions about their career which allows them to relax before 'an iffy subject' is discussed.

\section{Who, what, when, where, why}

According to Comdt Mac Eoin's experience, interviewees tended to be retired which entailed 'they had less at stake' and 'say things they probably were never able to say during their career' which mirrors the US Senior Officer Oral History program which records an officer's testimony three to five years after retirement to allow reflection and to lessen restrictions that would normally be in place for serving military officers. Dr Mc Cafferty outlined the lack of records that he 'would have loved to have seen' with no account of how the decision to deploy to the Congo was taken posing the question ' $\mathrm{He}$ had to go off and do it, but how did they do it?' The loss of the opportunity to record the testimony of the senior leadership of the time resulted in a lack of detail surrounding many of the Defence Forces' seminal events within its limited history. The use of tacit knowledge and hand overs between deployments as a method of recording experiences and learning remains a risk if not captured formally.

Lt Col O'Brien who has 'experienced very good handovers' strongly supported a formalised system as it 'still doesn't justify the fact that nobody in the previous 50 years had written down a peace support doctrine for one of our key roles and for our most dangerous roles'. Lt Col O'Brien described the usefulness of the Military Archives Oral History Project as it is 'done with all ranks' matching the bottom up approach of the U.S. senate which recorded accounts outside of the leadership at that time. Lt Col O'Brien further suggested that following a mission overseas that 'all battalion commanders, all of the senior Non Commissioned Officers and then a selection of other ranks would be brought together and do a brief and after-action review of the entire mission. What have we learned? What did we get right?' The suggestion by Lt Col O'Brien could be facilitated by use of the group interview method which he posits could be further supported by use of a video recording. The recommendation to capture ' 10 key people from each trip' is shared by Comdt Mac Eoin who further recognises the challenges of operational security issues when taking testimony from serving members immediately after their deployment.

\section{Lessons and reflection}

Cpl Mick Whelan clearly summed up the value Oral History as 'it brings the whole thing to life and it makes you actually think about what you would do in that situation'. The reflection and the conceptual application as described by Cpl Whelan was one which Kolb utilised in his experiential learning model. Cpl Whelan suggests that it is only after an event that one gets an opportunity to reflect as 'you're not really thinking about what that means. It is only afterwards when you're sort of interviewing other people that you tend to reflect on these'. The provision of time to reflect is encapsulated in the Canadian Oral History model which records testimony three to five years after retirement to allow 
this time to reflect. Cpl Whelan outlined the learning he has undergone since conducting interviews. Despite having served in Lebanon, 'you know what's going on to a certain extent. You don't really until you come out of that situation and you look back and go. Oh my god, I didn't realise how dodgy that period was'. The importance of multiple sources on similar events is further validated by Cpl Whelan who continues to learn more about Lebanon through multiple and varying views and an opportunity to reflect, 'I've only learned how dangerous Lebanon was through the oral histories, do the Irish people not realise how much danger our soldiers were in out there? The oral histories have definitely helped me understand what I was a part of half my lifetime ago'. Alongside organisational memory, the use of oral history provides an opportunity to educate the wider public about the roles of the Defence Forces overseas as outlined by Whelan, 'that's one of the exciting things about oral history because I don't think the Irish people or the Irish population understand the Irish soldier'.

Lt Col Harvey provides a personal professional reflection on the use of Oral History in that it helped him understand that a particular challenging task:

was done, and so could be done again and was hugely encouraging and confidence building. This did not embolden me, rather fortified me with the knowledge to better assert my judged decision on a situation should I face it.

Dr Mc Cafferty reflected on his research on the Congo and not realising how difficult it was for the first personnel who deployed to the Congo, 'It wasn't until I did the research that I appreciated how difficult it was and particularly for the advance party of the 32 Infantry Battalion who went out there'. The life-long learning espoused by the Defence Forces Leadership Doctrine is discussed by Dr Mc Cafferty who outlined that 'everybody was learning the whole experience, if you look at the 36 Infantry Battalion in attack, as I reckoned it, I could be wrong but they had three companies committed, I mean that's the battalion'. The 'Battle of the Tunnel' involved a Battalion which is the largest offensive operation conducted by the Defence Forces overseas. While reflection on past events is possible, the real risk remains in not only documenting the events of this 'Battalion in attack' but to learn from what remains the largest engagement in Defence Forces history.

Many of the lessons outlined by the interviewees were upon reflection of their personal experiences or the experiences of those they had interviewed. The use of handovers plays a central role in the passage of information between personnel serving overseas according to Col Feely, 'these guys would give you little clues or give you little steers'. Col Feely also outlined that 'lessons learned, and in future operations you would try to employ those lessons and learn from them and use them and maybe be more wary of the signs of potential trouble than had been up to that point'. This lesson is shared by Dr Mc Cafferty who described the patrol in Niemba as having a very casual approach despite the known threat in the area ${ }^{3}$.

A practical example of the use of Oral History as a learning tool was provided by Comdt

\footnotetext{
${ }^{3}$ Niemba was the location of an ambush of Irish troops which took place on $8^{\text {th }}$ November 1960 while serving with the United Nations in the Congo. 9 Irish soldiers lost their life in what is the greatest loss of life in the Irish Defence Forces in a single incident.
} 
Mac Eoin who at the time of the interview was a class officer in the Cadet School. Comdt Mac Eoin outlined that each lesson or exercise was given a reason or purpose which he describes as 'the battle incentive for learning this weapon is that someday you will need to fire in defence of your life or whatever'. This wider understanding of the potential application of a skill provides a context for soldiers in learning a new skill. Comdt Mac Eoin describes a student from his Cadet Class during a debrief of a field assessment who provided feedback that 'we wished there would have been a bit of learning beforehand about historical case studies of section commanders in action, so we could contextualise what it is we were being asked to do'.

The interviews conducted as part of this research provided a number of themes which were analysed and discussed. The findings provide many of the key components of the Defence Forces Leadership framework providing practical applications of the areas the Defence Forces espouses to promote. Key areas were the presence of Defence Forces values, character, competence, mission command and the need to augment the written record with the social and behavioural insights. These key areas identified can then be provided through Oral History for use as a leadership development tool. The findings also indicated the supplementary nature of Oral History to the written record which was strongly supported by the interviewees and one which could fill the gaps against the solely written report such as the unit history.

\section{PART 4: Conclusion}

The Defence Forces Capstone Doctrine and Defence Forces Leadership Doctrine outline the need to codify sixty years of overseas experience. With no peace support operations doctrine in place, the risk of organisational memory loss, forgetting lessons learned on overseas service and tangible examples on how Defence Force members have lived the values and virtues is very present. This article set out to examine and answer the questions: how can Oral History enable the Defence Forces Leadership Doctrine in its role of leadership development and capture the organisational memory in a formal method away from the oral tradition and tacit handover of information?

The need remains to capture the experiences of personnel at home and overseas as part of the Defence Forces Leadership Doctrine alongside current methods for records management and documenting operations in the Defence Forces. Current literature on experiential learning utilising both internal Defence Forces Oral History projects and international Oral history projects in the US and Canada provides successful examples and opportunities for a wider programme of capturing organisational memory and assisting in leadership development. The current leadership framework provides a platform for leadership development in the Defence Forces which can utilise Oral History while recognising the challenges Oral History presents. The wide range of methodologies of bottom up and top down together provide a more balanced approach with different viewpoints.

The use of Oral History can provide tangible examples of the values espoused by the Defence Forces which will aid in the evolution of leadership development providing context 
and a greater understanding of the challenges that personnel encounter at home and overseas. There is no current Peace Support Operations doctrine nor any formal methods of capturing the experiences of personnel at present. The written record does not adequately provide for understanding why decisions were made or provide context of the operational environment. The extent to which an Oral History project collects testimony such as the Military Archives Oral History Project is dependent on available financial and human resources. Recommendations of the interviewees indicate a significant opportunity to capture the experiences of Defence Forces personnel as a way of teaching leadership, providing context to Defence Forces values, character and competencies. The recommendations also identify a process by which the Defence Forces can capture the experiences upon which both our Defence Forces Capstone Doctrine and Defence Forces Leadership Doctrine is based.

A number of recommendations arise from the research in relation to the identification of value based leadership and capture of organisational memory. Recommendations also include the integration of Oral History as an official record of the Defence Forces using an active collection policy. The setting up of an Oral History programme can be integrated into a process of reflection and lessons learned using proven methodologies for Oral History projects.

\section{Values based leadership}

The criticality of Defence Forces values of physical courage, moral courage, selflessness, integrity, respect and loyalty were evident in the interviews, providing tangible examples upon which the Leadership framework can be brought into context. The importance of character, competence and mission command were also reflected across the interviewees. The original questions had not intended to research the centrality of values in leadership development offering a very positive opportunity should focused questions be provided on this area.

There are no suggested questions to collate focused data on subjects of interest such as leadership. Semi-structured interviews should remain in place for Military Archives Oral History Project with additional focused questions to provide tangible applications to leadership development to include values, competence, character, mission command and successful leadership traits. The development of lesson plans using Oral History testimony and the Defence Forces leadership framework for use by Defence Forces educational institutions could provide tangible examples of Defence Forces' values in action. There remains an abundance of serving and retired members of the Defence Forces and others including Distinguished Service Medal holders and Military Medal for Gallantry holders which will provide the tangible examples of Defence Forces values for use in leadership development. The successful collection of Oral History interviews in addition to Distinguished Service Medal \& Military Medal for Gallantry holders from their fellow soldiers may counter any reluctance on their part to discuss their own actions.

\section{Organisational memory}

There is no process by which the experiences of personnel are captured despite its central role in leadership doctrine and capstone doctrine. Research using written documents alone does not adequately provide sufficient information to understand why decisions were 
made. Tacit information, oral tradition and the 'Handover - takeover' process remains the current system for the passing of information. This system while effective for the transfer of pertinent information from individual to individual orunit to unit, risks losing information that is not deemed currently important. Given the intra - generational timelines of modern operations, information from start to finish of a mission or operation may be lost. The capturing of this organisational memory can be achieved through the training of additional personnel to conduct interviews of units on completion of their deployment. The development of semi-structured interviews with focused questions will enhance the successful capture of organisational memory of a deployment for both short and long-term operations. The capturing of a wider socio, economic and political background providing a more comprehensive organisational memory can be achieved through interviews of locals within the mission, civilian agencies or the Department of Defence.

\section{Differences between oral testimony and the written record}

The written record is an important component of recording overseas and domestic activities and providing accountability of actions to include reports and unit histories. The written record does not always capture the human element of why decisions were made or a deep understanding of the challenges and the operational environment faced by personnel on operations. The dangers of an overly positive official report does not provide an opportunity to reflect on mistakes or lessons learned. Variations on the written record and what occurred during a deployment or action may not be apparent using only a written record. The use of Oral History can allow for further exploration on a particular subject. The establishment of an actively collected and official Defence Forces record as part of a wider unit history would allow key events in Defence Forces history be captured when current in the minds of the participants. Tracing of sources from previous operations and activities such as Rwanda, Operation Pontus or the 2012 Re-organisation could also be considered.

\section{Reflection and lessons}

Reflection on past events provides an opportunity to evaluate decisions and performance, taking account of all information that may not have been available at that time or during an operation when time is limited. The lessons learned from Oral History can take account of social and personnel issues that can't be captured adequately on the written record. Oral History can provide a personal insight into their experiences which provides a voice that is more relatable to personnel that will be operating in similar circumstances. The normal presence of fear in a dangerous situation provides reassurance to an individual which may assist a member of the Defence Forces deal with this emotion should it arise. The lessons learned and reflections in Oral History format can be incorporated into a lessons learned cell.

\section{Methodology/triangulation}

The Defence Forces has experience of managing large scale Oral History projects including the Bureau of Military History and the Military Archives Oral History Project. A deliberate programme outlining particular areas to be captured could be developed to include both a top down and bottom up approach. The capture of current events on completion of a tour 
of duty, operation or event will allow for a greater level of detail while a follow up interview three to five years will provide a more reflective look back on the events. A second set of interviews could include personnel who were not in the original set of interviews for triangulation of the information. Suggestions for the collection policy include major incidents/events, overseas deployments. Use of the top down approach to include Chief of Staff or General Staff three to five years after retirement to allow for reflection and avoid any risk of being unable to speak in uniform provides a more strategic view. This top down approach could also be applied to the retired Department of Defence staff to allow for their reflection and insight into policy decisions. The bottom up approach provides an opportunity to include smaller missions and deployments which risk being forgotten such as Rwanda and observer missions. The continued use of external academics and practitioners provides a continued verification of the methodology of the Military Archives Oral History project ensuring the project can remain in line with best practice. External validation and a collection plan will assist the project with potential risks of project creep, security and information classification concerns. A project plan will also allow the project to focus on identified knowledge gaps, overseas missions, actions, events and the identification of personnel for interview as part of a leadership development programme and the capture of organisational memory.

\section{Implications}

The challenge of conducting a wider project scope in terms of resources and finance is acknowledged but can be mitigated by the valuable resource it provides for leadership development and organisational memory. The value to the Defence Forces in terms of fulfilling the path espoused by the Leadership Doctrine will recognise the importance of Defence Forces deployments overseas and domestic roles and the centrality of leadership development of Defence Forces personnel. The extension of the Military Archives Oral History Project will also provide a significant resource for informing and creating public awareness of the role of the Defence Forces both domestically and internationally as part of Ireland's national interests. The use of tangible examples can greatly enhance Defence Forces leadership development education and provide an opportunity to capture the commitment and dedication of former members who have provided many years of dedicated service. The extension and promotion of the Military Archives Oral History Project is an opportunity to reflect on their service and provide the acknowledgement of their contribution to the state. Widening of the scope of Oral History testimony to civilian staff and local populations, as demonstrated by the Lebanon project in 2018, provides a different context and view enhancing Defence Forces self-awareness and the role it plays on behalf of the public. This additional view will also assist in analysing potential issues or provide context to enhance the Defence Forces decision making process.

The Military Archives Oral History Project continues to grow and develop successfully within the Military Archives and has undertaken innovative projects including the visit to collect testimony in Lebanon in 2018 and the integration of old testimony thus ensuring its on-going preservation and access. It should be recognised that any increase in scope is difficult within current resources as the project remains one of many equally important roles carried out by the Military Archives.

This article aims to show how the use of Oral History can be utilised in tandem with 
the Defence Forces Leadership Doctrine in leadership development and promote the values of the organisation. The use of Oral History provides the human side to our operations both at home and overseas and captures the nuances that are often absent in the written record. The increased scope for the Military Archives Oral History Project to capture these experiences will provide benefits both intrinsically for organisational memory and as a leadership tool but also provide an engagement tool for the public. The use of Oral History will not only recognise Defence Forces veteran's service but can also provide a method to enhance the public's knowledge and appreciation of the work carried out by members of the Defence Forces on their behalf. The expansion and promotion of the Military Archives Oral History Project through a resourced and focused project plan will ensure that the Defence Forces can gather tangible benefits and provide significant value for money in terms of answering the question in the provision of an excellent leadership development tool and capturing an important part of Defence Forces history both domestically and abroad.

Please note that the views expressed in this article are those of the author alone and should not be taken to represent the views of the Irish Defence Forces, the Command and Staff School or any other group or organisation.

\section{Bibliography}

Beiner, G. (2017, September 21). Bodhaire Uí Laoire. Retrieved from UCD: http://www.ucd.ie/pages/99/articles/beiner.html

Brown, A. (2007). Oral History at the Canadian War Museum. Canadian Military Museum , 61-64.

Bureau of Military History. (1948, May 10). S File 851. Dublin. Bureau of Military History. (1957). Report of the Director. Dublin.

Centre, U. A. (2018, Jan 04). https://ahec.armywarcollege.edu/oralhistory.cfm.

Retrieved from Senior Officer Oral History Programme:

https://ahec.armywarcollege.edu/oralhistory.cfm

Coffman, E. M. (2001, Spring). 'What really interests me are the People': Edward Coffman on Soldiers, Scholars, and the New Military History. (J. R. Harris, Interviewer)

de Bock, P., \& Olsthoorn, P. (2016). Leadership development of Junior Army leaders: a Dutch perspective. Journal of Military and Strategic Studies, 154-170.

Defence Forces. (2016). Defence Forces Capstone Doctrine. Kildare: Defence Forces.

Defence Forces. (2016). Defence Forces Leadership Doctrine. Kildare: Defence Forces.

Defence Forces, (1961). 36 Infantry Battalion Unit History. Defence Forces.

Defence Forces, (2013). Administration of Overseas Service. Administrative Instruction CS5 New Series. Kildare: Defence Forces.

Department of the Army. (1993). Army Regulation (AR) 870-5 Military History: Responsibilities, Policies, and Procedures. US Army Regulations, 1-28. 
Durflinger, S. (2002). The Canadian War Museum Oral History Project. Canadian Military Journal , 61-62.

Farrell, T. A. (2013). The Taliban at War: inside the Helmand insurgency, 2004 - 2012. International Affairs, 845-871.

Ferriter, D. (2003, Autumn). In such deadly earnest. Dublin Review, 1-7. Retrieved from Dublin Review.

Gerras, S. C. (2008). Thinking critically about critical thinking : A fundamental guide for strategic thinkers. Department of Command, Leadership and Management, U.S. Army War College.

Gray, C. (2011). The Strategist as Hero. JFQ, 37-45.

Holden, M., \& Lynch, P. (2004). Choosing the Appropriate Methodology: Understanding Research Philosophy. The Marketing Review, 397-409.

Hong, H. E. (2016). Through the looking glass: The Critical Role of Oral History in understanding local perspectives. The Concord Review,183-198.

Hughes, B. C. (2017). Contested Memories: Revisiting the Battle of Mount Street Bridge. British Journal of Military History, 2-22.

J. Nyham, A. F. (2016). Why Oral History? Computation and the Humanities, 21-36.

Kirwan, C. (2015). Learning from experience and its role in leadership development in the Defence Forces, MA LMDS, Maynooth University, Kildare.

Kohn, R. H. (1997). The practice of Military History in the U.S. Government: The Department of Defense. The Journal of Military History, Vol 61, No 1, 121-147.

Kolb, D. (1984). Experiential learning. New Jersey: Prentice Hall.

Kolb, D. B. (1999). Experiential learning theory and new directions. In R. S. Zhang, Perspectives on cognitive, learning, and thinking styles, 227-247. New Jersey: Lawrence Eribaum.

Lofgren, S. (2006). U.S. Army guide to Oral History. Washington: UPA.

Mac Conmara, T. (2016). Military Archives Oral History Project Guide. Dublin: Military Archives.

Mc Garry, F. (2011). Too many histories? The Bureau of Military History and Easter 1916. History Ireland, Vol 19 No 6 November December, 22-29.

Miettinen, R. (2000). The concept of experiential learning and Dewey's theory of reflective thought and action. International Journal of Lifelong Education, 54-72.

Military Archives. (2002). An introduction to the Bureau of Military History 1913- 1921. Dublin: Military Archives.

Morgan, G., \& Smircich, L. (1980). The Case for Qualitative Research. Academy of Management Review, 491-500.

Morrison, E. (2003). The Bureau of Military History Witness Statements as Sources for the 
Irish Revolution. Retrieved from Bureau of Military History: http://bureauofmilitaryhistory.ie/files/Bureau_of_Military_witness_statements\%20as _sources\%20for_the_Irish\%20Revolution.pdf, accessed 11 November 2017.

Murphy, S., Dingham, M., \& Mensch, K. (2011). Experential leader development at the United States Marine Corps Intelligence: A pilot study evaluation.

Organizational Development Journal, 23-38.

O'Donoghue, D. (2006). Army's Congo Mission Casts a Long Shadow. Irish Studies in International Affairs, 17, 43-59. Retrieved August 22, 2020, from http://www.jstor.org/stable/30002097

OHNI. (2017, September 21). About OHNI. Retrieved from Oral History Network of Ireland: http://www.oralhistorynetworkireland.ie/about/links/

Philips, D. (2010). What lies beneath the history of Conflict? Using personal testimony for learning. Oral History Society, 114-117.

Remenyi, D., \& Money, A. (2004). Research supervision: for supervisors and their students. London: Academic Conferences Limited.

Reville: Irelands Military History. (2018, Feb 14). Irish Peacekeepers on the Offensive: An interview with Congo Veteran CQMS Jimmy Clarke (Retd). Retrieved from Ireland's Military Story: https://www.irelandsmilitarystory.com/preview/eyewitness/14-ten-daysin- elisabethville

Ritchie, D. (2016). Top down/Bottom up :using oral history to re-examine government institutions. Oral History, Vol 42, No 1, 47-58.

Robinson, J. (2016). Connecting Leadership and Learning: Do versatile Learners Make Connective Leaders? Higher Learning Research Communications, Vol 6, No 1, 1-16.

Robson, R. (2011). Real World Research (3rd Ed). West Sussex: John Wiley \& Sons Ltd.

Rottman, P. (2016). Toward a Realistic and Responsible Idea of Stabilisation. International Journal of Security \& Development, 1-14.

Roy, R. (1988). Old Soldiers Never Lie: Oral History and Military History. Archivaria, 169-172.

Silverman, D. (2000). Doing Qualitative Research: A practical handbook. London: Sage Publishing Inc.

Topping, S., Duhon, D., \& Bushardt, S. (2006). Oral History as a classroom tool: learning management theory from the evolution of an organisation. Journal of Management History, 154-166.

Trevor-Roper, H. (1969). The Past and the Present. History and Sociology. Past and Present, Oxford University Press, 3-17.

Walsh, J., \& Ungson, G. (2001). Organisational Memory. Academy of Management Review, 57-91.

Whelan, Michael. (2006). The Battle of Jadotville, Irish Soldiers in Combat in the Congo 
1961. Dublin: South Dublin Libraries.

Wong, L, Bliese, P and Mc Gurk, D (2003). Military Leadership: A context specific review. Carlisle: The leadership quarterly, 657-692.

Yardley, S., Teunisssen, P. and Dornan, T (2012, Jan 30). Experential learning:

Transforming theory into practice. Medical Teacher, 161-164. 